\title{
Perhaps by Skill Alone
}

\author{
CONNIE MISSIMER
}

"...think how Bacon shined, the wisest, brightest, meanest of mankind." -Alexander Pope

\section{Overview}

This article questions a view dominant among theoreticians of critical thinking: that the critical thinker has certain character traits, dispositions, or virtues. ${ }^{1.2}$ Versions of this theory (hereafter called the Character View) have been advanced without much analysis. The impression is that these traits or virtues are obvious accompaniments to critical thinking, yet such is not the case. Versions of the Character View are inconsistent; even within one version unlikely scenarios arise. Furthermore, historical evidence can be brought against this view. Most people assume that the greatest contributors to intellectual progress would be critical thinkers. Yet a number of intellectual giants, including Marx, Rousseau, Bacon, Freud, Russell, Newton, and Feynmann lacked many of the traits which the Character View holds to be necessary for critical thinking. This discrepancy calls into question the connection between having certain dispositions or virtues and the ability to think critically. Rather than concluding that these and other great thinkers cannot have been critical thinkers, one can subscribe to an alternative view which makes no claims about character, namely that critical thinking is a skill or set of skills (hereafter, the Skill View). According to this view, a critical thinker is someone who practices the skills of critical thinking frequently, just as a mathematician is a person who does mathematics frequently. Critical thinking is here defined as the consideration of alternative theories in light of their evidence, a definition which I believe encompasses the skill criteria of Ennis and Paul. The Skill View has for the most part been disparaged, ${ }^{3}$ yet the evidence in its favor would appear to be stronger; it has the advantage of theoretical simplicity; and it does not smuggle in moral prescriptions, leaving ethics instead to the scrutiny of critical thought. Finally, it is arguable that an historical version of the Skill View can show critical thinking to be more exciting than any version which the Character View has offered thus far.

\section{Concrete application of dispositions is problematical}

Over the past two decades, each writer holding a Character View has come up with a list of attitudes, dispositions, or virtues which he claims are necessary for critical thinking. By now there are over twenty such traits, including the following:

patience, humility, open-mindedness, impartiality, courage, readiness to submit to criticism, control of discordant passions (Dearden); integrity,empathy, perseverance, faith in reason, a passionate drive for clarity, accuracy, listening sympathetically to opposing points of view, fair-mindedness, justice, (Paul); objectivity, consistency, intense aversion to contradiction, repugnance of error, disgust at evasion, love of reason, love of truth, admiration of theoretical achievement (Scheffler); self-confidence, a positive self-image, emotional security, [being] capable of distinguishing between having faulty beliefs and having a faulty character (Siegel). ${ }^{4}$ 
This sizable repertoire offers a host of puzzles. Each of the terms is hard to pin down. For example, what does it mean that to think critically one must have patience? One person might feel that he is patiently working over a problem, another person feel her impatience at getting an answer. Yet these descriptions tell us nothing of the quality of his or her thought. Similarly, must one be impartial sub specie aeternitatis, or may flawed efforts count? Might one think a theory daft yet be impartial? Impartial by whose lights? Without benefit of examples, it is difficult to say. Among these authors only Paul has offered definitions to help answer such questions.

The lack of elaboration leads to the problem of how these concepts interrelate. For example, does Scheffler view his "respect for the considered arguments of others" as open-mindedness (Dearden's trait)? It would clarify matters if each theoretician showed how the traits he espouses are (not) compatible with others'. This suggestion is not based on the premise that any theoretician is accountable for others' views, but that comparison would yield clarification.

Another puzzle is whether, within one theoretician's list, all items are equally necessary, For instance, to take Scheffler's list, can a critical thinker be consistent but not have an aversion to contradiction, or love truth but not be disgusted (but instead amused) by evasion? Catholic women in the 1950 's were reported to have felt emotionally secure in their environment while lacking a positive self-image. Were such Catholic women excluded from the possibility of critical thinking because they lacked a positive self-image? One wonders why this must be the case.

It is possible to imagine versions of traits which don't mesh. To take a hypothetical case, if Susan makes a considered argument which Margaret believes to contain distortions, can Margaret be revolted by Susan's distortions while feeling respect for her considered argument? Revolt and respect are odd emotions to feel simultaneously. Why couldn't Margaret respect the considered argument yet be amused or fascinated by the distortions without relinquishing her status as a critical thinker? And for her part, if Susan had a concern for accuracy and later realized that her argument had contained distortions, must Susan now feel revulsion at her earlier argument? She might instead experience surprise or delight at the new theoretical possibilities that she now sees. ${ }^{5}$ It is difficult to see why we must conclude that Susan was not thinking critically just because she failed to respond in a manner prescribed by a version of the Character View.

\section{The argument that ideals don't require evidence}

Those adopting the Character View might argue the weaker case that, rather than necessary to critical thinking, (some of) the traits they espouse are ideals for which it is necessary to strive if one is to be a critical thinker. Since they are ideals, the argument might run, anyone requesting historical or other evidence in support of the Character View would commit the naturalistic fallacy of proceeding from what is to prescriptive inferences for future critical thinkers. So evidence here is irrelevant.

This argument begs the question whether traits of the Character View should be considered ideals over other possibilities, such as amusement at distortions, or the null hypothesis that no particular disposition or attitude is preferable for everyone. Say that we were entertaining the possibility of intellectual playfulness as an ideal-on what basis should we choose between playfulness on the one hand and perseverance or control of discordant passions on the other? The salient question is: Which (if either) works better? It would therefore seem that even in the realm of choosing among ideals we are cast back upon some kind of appeal to experience as arbiter; intellectual history has shown that gathering evidence is less risky 
than relying on opinion alone. So we end where we started, at the need for evidence of some sort about the actual traits of people whose thinking has by common consensus demonstrated great critical acumen. Biographies, case studies, interviews, or even experiments are evidentiary possibilities to help us decide which, if any, character traits are necessary for critical thinking.

\section{Biographical evidence and the Character View}

Biographies of several great thinkers suggest that aside from the habit of critical thinking, they have no dispositions or attitudes in common. In fact, the diversity is surprising, ranging from people of exemplary, to ordinary, to venal character. As noted earlier, attributes of the Character View are fuzzy at best. Yet one imagines that Marcus Aurelius, John Stuart Mill, Ernest Renan, and Henry Sidgwick have the right stuff: Henry Sidgwick had admirable patience, was always quick to perceive and to enter the point of view of a writer; Marcus Aurelius had great humility; Mill made a passionate attempt to be fair to all sides of a case. ${ }^{6}$

A biography of Sir Isaac Newton, on the other hand, reveals ordinary foibles. He was extremely sensitive to attacks on his optical theories, refusing to have any contact with his critics and for a time refusing to publish anything more until his friend Edmund Halley persuaded him to put out his third book of the Principia. ${ }^{7}$ Bertrand Russell repeatedly lied about having argued throughout the late ' 40 s for a preemptive nuclear war against Russia, finally admitting that he had repeatedly made such an argument. ${ }^{8}$ Richard Feynman, among the greatest twentieth-century physicists, recounts his disposition to play with physics, to enjoy it. He started to work on the theory for which he won the Nobel Prize by fooling around with equations derived from watch- ing a spinning plate that a student had thrown in the cafeteria. The life of this "curious character" was by his account hedonistic, and he admitted he was rude when responding to ideas that he believed incorrect. ${ }^{9}$

Some celebrated thinkers were venal. Rousseau took advantage of everybody, felt that they were out to take advantage of him, and was thoroughly convinced of his moral and intellectual superiority over all others. Marx was anti-Semitic, cheated tradespeople, and had a servant whom he paid nothing, made pregnant, and afterwards refused to acknowledge the child. ${ }^{10}$ Evariste Galois developed the theory of equations, one of the most original discoveries in the history of mathematics, as well as a number of other remarkable theories. He appears to have been a hothead whose extreme actions got him into trouble. He died in a duel with a friend because of a woman. ${ }^{11}$ The 17th century English physician William Harvey, who discovered the circulation of the blood and laid the basis of modern medicine, was temperamental and eccentric. As a youth, "he wore a dagger in the fashion of the day and was wont to draw it on slight provocation."' 12 The consensus about Sir Francis Bacon is that he was a cold fish, who betrayed colleagues and indulged in political intrigue. ${ }^{13}$ Recent scholarship on Freud's life reveals a man who sometimes claimed cures where there were none, and who on occasion distorted the facts of his cases to prove his theoretical points. In one little-known case that barely missed becoming a major scandal, Freud induced two patients to divorce their spouses and marry each other, then hinted that the man should make a generous donation to his psychoanalytic fund. Freud burned many of his papers at different points in his life and destroyed most of his case notes. These new revelations portray a man far more prone to human failing than his legend has allowed. ${ }^{14}$

Given this astonishing range among acknowledged great thinkers, the most 
reasonable conclusion is that one can be a great thinker without to any significant degree having the traits advocated by the Character View. But is a great thinker necessarily a critical thinker? To answer 'no' lands one in some difficulties.

\section{The Character View excludes many great thinkers}

Given the insistence of the Character View on traits such as patience, humility, and readiness to submit to criticism, then Marcus Aurelius, Ernest Renan and Mill probably count as critical thinkers, but it appears that Marx, Rousseau, Newton, and Freud would be excluded as might Russell, Feynman, Galois, and Harvey. These excommunications lead to the odd result that relatively minor figures in intellectual history count as critical thinkers, while many who made great contributions do not. If they cannot also be considered critical thinkers, then the notion of critical thinking would seem to be reduced to idiosyncratic judgments by theoreticians of critical thinking. Max Black warned against this sort of result, born of the best intentions:

Fired by enthusiasm for an ideal of 'reason' or 'rationality,' a thousand writers have offered persuasive definitions of what they think ought to be valued. In this way zeal breeds distortion... Too often... we are invited to treat as self-evident what badly needs argumentative support. ${ }^{15}$

\section{Great thinkers have only critical thinking skills in common}

The hypothesis that skills alone might suffice to explain critical thinking can rest on the evidence of what great critical thinkers share. Their critical thinking is in accordance with the definitions of the skill by Ennis and Paul. According to Ennis, critical thinking is reasonably deciding to believe or do something. For Paul, it is dialogical reasoning, the judgment of argu- ments in relation to counterarguments. ${ }^{16}$

To illustrate that these are sufficient yardsticks for critical thinking, suppose one finds a piece of writing that entails a conclusion reasonably arrived at through consideration of alternative arguments. It would seem that, based on the writing alone, one would be entitled to conclude that the author had done critical thinking. If upon following the author's writing for ten years one found it for the most part to satisfy this criterion, it would seem that one could justifiably call the author a critical thinker without the need for any information about the author's character. Great critical thought throughout history has always been judged according to the thought itself, not the character or motivation of the thinker, and presumably the Character and Skill Views agree on this point. The difficulty arises with the question whether one can reasonably infer that a writer must have possessed specific character traits to have done consistently fine critical thinking for ten years. We have seen historical evidence favoring silence on the issue of necessary traits.

\section{Untoward results of the Character View}

Unfortunately, the Character View coupled with biographical information about great thinkers permits the anti-intellectualist conclusion which historian Paul Johnson offers in his book, Intellectuals:

\footnotetext{
...I think I detect today a certain public skepticism when intellectuals stand up to preach to us, a growing tendency among ordinary people to dispute the right of academics, writers and philosophers, eminent though they may be, to tell us how to behave and conduct our affairs. The belief seems to be spreading that intellectuals are no wiser as mentors, or worthier as examplars, than the witch doctors or priests of old. I share that skepticism. ${ }^{17}$
}

Johnson has taken the Character View argument "If they are critical thinkers, then they will evince virtues $X, Y, Z$," and employed Modus Tollens to take the logically 
valid contraposition: "They did not evince virtues $X, Y, Z$, therefore they are not critical thinkers ("wise mentors')." The inescapable implication is that we should pay no attention to their ideas.

This line of thought is worrisome. Why should we tear the mantle of critical thinker from a Marx or a Rousseau on the basis of how they lived? To do so is to reason in an ad hominem fashion and misses the point that intellectuals advocate theories which they consider to be true. To insist that their lives have any bearing on the truth of their theories seems quite beside the point. Yet the Character View enjoins this unfortunate entanglement.

\section{The Skill View is the minimalist position}

Could one remove every character trait from contention for critical thinker? Some might insist on what might be termed the minimalist character position: that the only trait necessary is a disposition to think critically (reasonably decide based on alternative arguments). Unlike the traits advocated by the Character View, this trait approaches the tautological: To be considered a critical thinker you must do a lot of critical thinking as a result of having wanted to. Similarly, to be (thought) a mathematician, historian, sailor, you must do a lot of mathematics, history, sailing as a result of acting on your disposition to do so. One could think of these dispositions to do critical thinking (or mathematics, sailing, etc.) as character traits; one could as easily think of these activities as habits born of skill and enthusiasm to keep up the habit.

Accepting that we teach critical thinking to encourage this disposition/habit to think critically, and reflecting on our efforts to teach it, two alternatives come to mind:

1. tell students that they should acquire this disposition across disciplines and in their lives;

2. teach the skills of critical thinking across disciplines and have students practice them across disciplines and in their lives, insuring that they do so by giving specific assignments.

If you tell students that they should have the disposition but don't teach the skills, students will not be able to think critically. If you get them to practice the skills in a myriad of areas but do not tell them that they should have the disposition to do critical thinking, you are teaching the disposition in the sense that you are instilling the habit of critical thinking. Prejudice against the concept "habit" is most unfortunate. There is the habit of having a beer every night before bed and there is the habit of solving differential equations. Like the latter, good critical thinking is an exquisite, complex habit made the more enjoyable precisely because it is habitual.

Whatever else may be said about the lives of the famous thinkers mentioned in this article, their biographies show them all to have been habitual critical thinkers, working for many years on their theories. This habit is both the necessary and sufficient cause of their having been critical thinkers.

\section{Has the Skill View been misconstrued?}

There are a number of unflattering versions of the Skill View--the word "mere" before "skill" predominates, rather than "only skill" or "just skill," although Siegel has offered a positive-sounding term, "pure skills." He objects to the notion of critical thinking as pure skills because it "sanctions our regarding a person as a critical thinker even though that person never, or only infrequently, thinks critically." ${ }^{18}$ This objection raises two interesting questions: "What does it take to become a purely-skilled critical thinker?" "Could a purely-skilled thinker never, or only infrequently, think critically?" First, what does it take to become a purely-skilled critical thinker? There is no skill I know of which comes without practice. We do speak of people who have "natural talent," as in "He has 
a natural talent for music," but we understand that to become a musician anyone must acquire an immense amount of skill through practice. On the other hand, we don't say "the skill of perfect pitch," presumably because perfect pitch has not been acquired through practice. We do say that someone is a skilled pianist, carpenter, scientist, and so on, because she has had a great deal of practice. The same is therefore probably true of critical (skilled) thinking. It takes a lot of practice to hold two or three competing theories in mind for evaluation. With instruction and practice, locating and entertaining theories becomes easier, and one's skill increases. It would seem, then, that "pure skill"' in the sense of skill devoid of practice does not exist-no person could be a critical thinker who had never, or only infrequently, thought critically, just as we know of no mathematician who had never, or only infrequently, done mathematics. So I would take the liberty of enlarging Siegel's term to "pure practiced-skill." 19

The second question raised by Siegel's objection to the Skill View is, then, "Could a purely practice-skilled thinker never, or only infrequently, think critically?', I think that the answer would be "Probably not,", if it is true that any skill, including critical thinking, is a set of habits. Of course, a person can choose to break a habit, just as she can work to change a disposition. It is also possible to practice a habit so narrowly that one does not generalize it because one is not in the habit of generalizing that habit, be it friendliness, careful handwriting, or critical thinking. But it is plausible that if practice in critical thinking is applied to a number of diverse academic and personal areas, the greater the chance that the pure practice-skilled thinker will apply these skills in choosing cars, political candidates, preferable theories in physics, psychology, and so forth. (A purely skills-oriented course could focus on a narrow application of critical thinking skills, or it could require critical thinking practice in a wide range of areas.) On the other hand, it is not clear how invoking dispositions would produce critical thinking unless one had acquired the skill of critical thinking through practice. Since the habit of critical thought appears necessary and sufficient to produce critical thinking, but (other) dispositions alone can't produce it, the role of dispositions other than habit is unclear at best.

\section{One skill view is exciting}

If critical thinking is merely skillbecome-habit, do we not serve the subject up as a very cold dish to students? We could, but needn't, if we look at critical thinking from Aristotle's point of view and from an historical perspective.

The Skill View can find support in Aristotle, who readily applied the term 'arete'-usually translated as 'virtue' but which is more precisely rendered 'excellence'-to things, including argument, ${ }^{20}$ In fact, he places 'theoretike,' theorizing, as the highest human activity, superior to moral virtues. 21

One conception of critical thinking throughout history is of an accretion of reasoned judgments on a myriad of issues by many people over time. This conception entails the notion that contrasting arguments on issues are vitally important to intellectual progress. By rationally deciding among increasingly refined hypotheses over centuries, critical thinkers have created immense intellectual, moral, and material benefits for succeeding generations to enjoy. ${ }^{22}$ One can offer this historical view as an argument that the skill of critical thinking has wrought immense good-and encourage students to argue against this view. The point is for students to consider past examples of critical thinking while practicing the skill. According to this version of the Skill View, if students get a glimpse of the wealth of theories which exist in every discipline and activity, they will be more likely to start on a lifetime intellectual journey. If they acquire the habit of critical 
thinking, we hope that they will go on to contribute their own strands to the weave of intellectual history. By this view the ultimate justification of critical thinking as an educational ideal is that looking at the past acts of critical thinking which form the backbone of each discipline will produce more critical thinking, 'theoretike,' on the part of students in their endeavors in every subject.

It is hard to see how this version of the Skill View could do harm, and it seems that a larger view of critical thinking, one that looks beyond the individual and his character, has potential for doing good. It focuses on great arguments, past and present, not on the arguers.

\section{The Skill View allows for free ethical theorizing}

Yet is a vital ingredient missing in the omission of ethical prescriptions from the consideration of critical thinking? Can any society afford to have educational institutions which would teach rationality divorced from basic moral principles and character questions? Siegel has argued that the justification of critical thinking must of necessity refer to the sort of person an educated person is; it must therefore refer to dispositions and character traits as well as skills and performances. ${ }^{23}$

This argument conflates two widely divergent ways of teaching critical thinking and morality. One way is to teach critical thinking as though it were necessitated by (a version of) morality, for instance justice, humility and so forth. This method seems to entail an uncritical acceptance of those morals, since they have been defined as necessary for critical thought in the first place. This uncritical "morality of critical thinking" seems to be what the Character View espouses.

Another way to teach critical thinking and morality is to teach only the skill, inviting students to use that skill to decide for themselves whether specific virtues are important in life (or necessary for critical thought). This second way, of a morality critically arrived at by the use of critical tools, is compatible with the Skill View, although the Skill View makes no stipulation to engage in moral questions. (That question, too, would have to be critically thought out). Ironically then, the Skill View is more open to ethical theorizing than is the Character View.

Scheffler makes one claim that would put him with the Skill View in this regard if he means to include the question of character and critical thinking:

Rationality... is a matter of reasons, and to take it as a fundamental educational ideal is to make as pervasive as possible the free and critical quest for reasons, in all realms of study. ${ }^{24}$

\section{Summary}

I have argued that the Skill View has much to recommend it. If one is to include some of the world's famous thinkers, then historical evidence is in its favor, it has the advantage of theoretical simplicity, and it does not entail ethical prescriptions, leaving all ethics, even the question whether any virtues are entailed in critical thinking, open to critical thought. One version of the Skill View can show critical thinking to be central to the evolution of intellectual life, thus making the consideration of alternative theories the keystone to all disciplines. This "historical-skills" version is arguably a better educational justification of critical thinking than questions of the character of critical thinkers.

Theoreticians of critical thinking who subscribe to the Character View could continue to maintain that certain traits are necessary or ideal goals despite evidence that this view excludes a number of history's greatest intellectuals. That odd result should temper confidence in the Character View, as should the large number of traits put for- 
ward, their relative imprecision, and the difficulty of seeing how they might play out in actuality. In any case, the notion of a critical thinker cannot be an idiosyncratic construct of theoreticians of critical thinking; if it is, why should any thinking person uncritically follow it? While we would prefer that obnoxious or destructive people not be critical thinkers, it appears that some have managed it despite our wish to the contrary.

\section{Notes}

1 Heartfelt thanks to Ralph Johnson and Lenore Langsdorf, who encouraged me to write this paper. Of course, responsibility for any errors is entirely mine.

2 Harvey Siegel writes of the "importance of incorporating tendencies, dispositions, and habits of mind into the characterization of critical thinking. He adds that "...critical thinking... concerns the characterization not simply of a set of cognitive skills or criteria of reasoning assessment, but more importantly of a certain sort of person... To recognize this is to recognize the depth of the concept of critical thinking, and the importance of character, values, and other moral dimensions of the concept." Educating Reason: Rationality, Critical Thinking, and Education, New York, Routledge, 1988, p. 10.

Richard Paul et al.: "To cultivate the kind of intellectual independence implied in the concept of strong sense critical thinking, we must foster intellectual humility, courage, integrity, perseverance, empathy, and fairmindedness." Richard Paul, A.J.A. Binker, Karen Jensen \& Heidi Kreklau, Critical Thinking Handbook: 4th-6th Grades. A Guide for Remodelling Lesson Plans in Language Arts, Social Studies, \& Science, Rohnert Park, California, Center for Critical Thinking and Moral Critique, p. 22. Cf. also, Richard Paul, "Teaching Critical Thinking in the 'Strong' Sense: A Focus on Self-Deception, World Views, and a Dialectical Mode of Analysis," Informal Logic Newsletter, Vol. 4, no. 2, 1982, p. 5.

R.F. Dearden not only states requisite virtues but writes of intellectual vices: "In the event of our failing to acquire these intellectual virtues, there is a whole range of vices; credulity, self-deception, precipitancy in judgement, superstition, rationalisation, wishful thinking, gullibility, prejudice and bigotry." Theory \& Practice in Education, London, Routledge \& Kegan Paul, 1984, p. 119. Also, R.S. Peters, Reason \& Compassion, London, Routledge \& Kegan Paul, 1973, pp. 75, 79.

John Passmore: " ". . being critical is more like the sort of thing we would call a "character trait' than it is like being skilled in a performance." From Chapter 9, "Teaching to Be Critical," in The Philosophy of Teaching, Cambridge, Harvard University Press, 1980, p. 166.

Istael Scheffler claims that the eight dispositions of character he puts forth are necessary conditions ("demands") not only for the rational life but for individual judgments: "Like moral character, rational character requires that ... the right emotions be attached to the right acts and judgments." Inquiries: Philosophical Studies of Language, Science and Learning, Indianapolis, Hackett, pp. 348-349.

I do not include Robert Ennis among proponents of the Character View, because his account of critical thinking details the skills required to assess arguments. Ralph Johnson has pointed out that Ennis's list of dispositions, e.g., "Seek a clear statement," "Seek reasons," are not really dispositions but "directives or maxims." (R. Johnson, "On Defining Critical Thinking: A Pragmatic Contribution," presented to the Canadian Philosophical Association, 1988.) More recently, Ennis has written of tendencies to exercise critical thinking, but these tendencies are, in his words, "included in the list of proficiencies." Ennis's reluctance to specify critical thinking character is, in my view, admirable, although he has been criticized for it. Whether Ennis would prefer to be considered as subscribing to a Character View is another question.

3 In The Philosophy of Teaching, Passmore's examples of "mere skill" include the skills of better pickpocketing and of executing people! op. cit., p. 169. Cf. Israel Scheffler, Reason and Teaching, where although rationality is "a precious instrument" it "is...not simply a tool used by a developed ego to solve its problems in the world, but enters, so to speak, into the very structure of the ego itself in so far as the ego is capable of identifying problems, formulating coherent choices, grasping propositions and maxims, and gauging their import for intended action." (New York, Bobbs-Merrill, 1973, p. 28.) 
(My italics.) It is not clear what the distinction is between the tool and the definition. Dearden, op. cit.; Paul et al., Critical Thinking Handbook, op. cit., p. 23; Scheffler, Inquiries, op. cit., p. 348; Siegel, op. cit., p. 41.

5 In a section titled "Emotions in the Service of Cognition," Scheffler argues the necessity of revulsion at distortion (p. 348) yet argues a few pages later for the significance of surprise, which can amuse, even enchant. Op. cit., pp. 358-359.

- Brand Blanshard, Four Reasonable Men, Middletown, Conn., Wesleyan University Press, 1984. The quote about Sidgwick, p. 231; about Marcus Aurelius, pp. 43-44; about Mill, p. 100.

7 Jacob Bronowski, The Ascent of Man, Boston, Little, Brown and Company, 1973, p. 226.

8 Paul Johnson, Intellectuals, New York, Harper \& Row, 1988. pp. 204-207.

9 Richard Feynman "Surely You're Joking, $M r$. Feynman!" Adventures of a Curious Character, New York, Bantam Books, 1985, pp. 157-58.

10 Paul Johnson, op. cit. On Rousseau, pp. 12-16; on Marx, pp. 79-80.

11 Tony Rothman, "The Short Life of Evariste Galois," in Scientific Genius and Creativity, New York, W.H. Freeman, 1987, p. 59.

12 Frederick G. Kilgrour, "William Harvey," ibid., p. 11,

13 Anthony Quinton, Francis Bacon, Oxford, Oxford University Press, 1982.

14 Frank Sulloway, Freud, Biologist of the Mind, New York, Basic Books, 1989.

15 R.F. Dearden, P.H. Hirst and R.S. Peters, eds., Education and the Development of Reason, London, Routledge \& Kegan Paul, 1972, p. 195.

16 "Critical thinking is reasonable, reflective thinking that is focused on deciding what to believe or do." Robert Ennis, "Goals for a Critical Thinking Curriculum," Developing Minds: A Resource Book for Teaching Thinking, Association for Supervision and Curriculum Development, 1985, p. 54. It is important to note that Ennis holds that it is possible to critically evaluate an argument or theory in isolation, a position that I don't agree with, which is why I favor Paul's conception of critical thinking in which, "one takes a... dialectical/dialogical approach (arguments need to be appraised in relation to counterarguments...) Paul, op, cit., p. 3. I favor Paul's definition, with the proviso that alternative arguments be judged in light of the strength of their respective evidence. By "argument" I also mean theory, and hypothesis. The major claim in an hypothesis, theory or argument is the conclusion, which must be supported or justified by good reasons which turn upon evidence. (Anyone who disagrees that critical thinking is the consideration of alternative arguments in light of their evidence would have to justify her position by offering an alternative theory along with supporting evidence.) I hope to show in a future article that Ennis's many skills and dispositions are reducible to this simple conception of critical thinking.

17 Johnson, op. cit, p. 342.

18 Siegel, op. cit., p. 6.

19 Cf. ibid., pp. 139-40, his discussion with Ennis which focuses on the notion of skills plus tendencies, but not on practice needed to acquire skills and tendencies.

20 Jonathan Barnes, Aristotle, Oxford, Oxford University Press, 1982, p. 78: "Aristotle can talk of the arete of an argument or of an axe as well as of a man: Human arete is human excellence-what it is to be a good human being-and it has only an indirect connection with what we think of as virtue."

21 Aristotle, The Nichomachean Ethics, London, William Heinemann (trans.), 1926, Book X, vii. $7-8$, pp. $626-627$.

22 For elaboration on this argument, cf. Connie Missimer, "Why Two Heads are Better Than One: Philosophical and Pedagogical Implications of a Social View of Critical Thinking," Normal, Illinois, Proceedings of the Philosophy of Education Society 1988, vol. 44, pp. 388-402.

23 Siegel, op. cit., Chapter 3.

${ }^{24}$ Scheffler, Reason and Teaching, p. 62. In a similar vein, Siegel notes: "By encouraging critical thinking, then, we teach the student what we think is right, but we encourage the student to scrutinize our reasons and judge independently the rightness of our claims. In this way...the student makes her own judgments regarding the appropriateness of alternative beliefs, courses of action, and attitudes." op. cit., p. 58 . I am advocating that this freedom refer to conclusions about dispositions for critical thinking as well, in which case the skill of scrutiny of reasons is the fundamental lesson, not dispositions. 